\title{
The Influence of Portuguese Syntax on the Learning of English as a Foreign Language: The Case of Null Subject
}

\author{
Filipe Losso Tati \\ Instituto Superior de Ciências da Educação (ISCED), Departamento de Ensino e Investigação em Lingua Inglesa, \\ Cabinda, Angola \\ Email: Losso.tati05@hotmail.com
}

How to cite this paper: Tati, F. L. (2021). The Influence of Portuguese Syntax on the Learning of English as a Foreign Language: The Case of Null Subject. Open Journal of Modern Linguistics, 11, 746-760. https://doi.org/10.4236/ojml.2021.115059

Received: July 17, 2021

Accepted: September 15, 2021

Published: September 18, 2021

Copyright $\odot 2021$ by author(s) and Scientific Research Publishing Inc. This work is licensed under the Creative Commons Attribution International License (CC BY 4.0).

http://creativecommons.org/licenses/by/4.0/

(c) (i) Open Access

\begin{abstract}
This research deals with the influence of Portuguese syntax on the learning of English as a Foreign Language, specifically the null subject parameter. This paper aims at seeing the influence of Portuguese syntax on the learning of English, mainly the influence of Portuguese phonological null subjects in the pupils' formulation of English sentences. An additional goal is to verify whether Portuguese syntax, especially the null Portuguese Subject had an influence on the $11^{\text {th }}$-graders' formulation of the English sentences. In this respect, it was hypothesized that if there is L1 possibility of null subject transfer in the formulation of English sentences, then $11^{\text {th }}$-graders will often drop the English subject; It is expected that $11^{\text {th }}$-graders of "Class B8" outperform those of "Class B7" as far as the English subject is concerned. Both qualitative and quantitative methods were adopted. On the other hand, the statistical tests used in this research in order to verify the invalidation or validation of hypotheses are the $\mathrm{t}$-test and the matched t-test. From the investigation conducted in this research, it was found that all the eleventh-graders to whom the test was subjected omitted the subject in their formulation of the English sentences.
\end{abstract}

\section{Keywords}

Language Transfer, Null Subject, Referential Subject, Non-Referential Subject, Pro-Drop

\section{Introduction}

The influence of the native language on the acquisition of a foreign language has long been the central issue of research in applied linguistics. Many researchers in the field of linguistics have done research on null subject languages; some even 
looked at the influence of English in the learning of the null subjects (e.g. Hyams, 1989; Liceras \& Díaz, 1999; Barbosa et al., 1995) and more recently in Prentza (2014). Some studies, however, have investigated the reverse process, that is, the influence of null subjects on the construction of English sentences (e.g. White, 1985, 1993; Valian, 1990) and recently studied in Antonova-Ünlü (2015).

It therefore follows that in Angola, a country where Portuguese is both the L1 and the language of instruction, pupils encounter difficulties in the formulation of English sentences. One of the numerous problems they face is the handling of the English subject.

This study investigated $11^{\text {th }}$-graders of a school in Cabinda. The study reveals that in their construction of the English sentences, these pupils tend to drop the subject due to the influence of Portuguese, their L1 and language of instruction. In fact, the following sentences are possible in Portuguese:

(a) Fuibrincar.

(b) Foi brincar.

The two above-mentioned sentences begin with different forms of the verb foi (to go). These verbal forms provide information on the subject, that is, Fui in (1a) and Foi in (1b) indicate the first person (I) and the third person (he or she) respectively.

In fact, the subject in Portuguese can be understood from the verb and the context. This state of affairs prompts learners to produce such ungrammatical sentences as $*$ Went to play for both Portuguese sentences mentioned in (1) above.

In English, however, the subject is obligatory and comes before the verb. The lack of equivalence of Portuguese null subjects in English is probably the source of difficulties these pupils face. In accordance with the problem above mentioned, the following research question was formulated:

What evidence is necessary in order to confirm that null subject influences the learners' construction of English sentences?

With the growing importance of English as a world language of communication in almost all domains of life, learners themselves are required to apply several communicative strategies to become effective communicators in English language, of which intelligible handling of subjects is of paramount relevance. It is against this background that the researcher designed this paper.

As for the limitation and scope of the research, it should be noted that this research is limited to the influence of the null subject on the learners' construction of English sentences. The sample of the research is limited to eleventh-graders at one of secondary schools in Cabinda, IMEC (Instituto Médio de Economia do Cabassango). The researcher assumes the sample to be representative of the population of the $11^{\text {th }}$-grade pupils. Hence, the findings of the research are valid and worthy of generalization.

The whole paper was oriented by the following research hypotheses:

1) If there is L1 possibility of null subject transfer in the formulation of Eng- 
lish sentences, then $11^{\text {th }}$-graders will often drop the English subject.

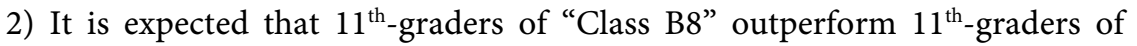
"Class B7" as far as the English subject is concerned.

Quantitative and descriptive methods have been employed in this research paper. The descriptive or qualitative research method helped the researcher to describe the various errors the subjects made. The quantitative methods, on the other hand, used testing and statistical techniques in order to verify the research hypotheses.

\section{Literature Review}

Definitions of subject follow.

\subsection{Subject}

Defining subject is not an easy task. Myriad attempts have been made to define the concept subject but the complexity involved in the notion, Svenonius (2002: p. 3), states "has defeated all attempts at a cross-linguistically valid definition." Many thinkers have defined and analyzed it in many different ways.

Aarts (1997: p. 8), for instance, uses the questions "Who or what carried out the action denoted by the verb?" and "Who or what is the sentence about?" to define the term subject. To him, subject is "the constituent that on the one hand tells us who performs the action denoted by the verb, and on the other hand tells us who or what the sentence is about." In their Nova Gramática do Português Contemporâneo, Cunha and Cintra (2001: p. 122) report the subject as "the entity about which something is said". Carter and McCarthy (2012) point out that subject is a term used to refer "the noun phrase which precedes the verb, and which indicates the 'doer' or agent of an action, or the participant that an event or state happens to or refers to". They also considered the subject as representative topic (who/what the clause is about), as in We baked some potatoes in the fire. In this regard, we answers Aarts' questions and is therefore, the subject of the sentence given by Carter and McCarthy.

It should be noted that subjects may differ according to whether they precede stative predicates or dynamic predicates. As Aarts (1997: p. 8) explains "subject which precedes a stative predicate can be found in the sentence-This room smells." He says:

In this sentence the question "Who or what carried out the action denoted by the verb?" is not valid because the room cannot perform the action of smelling and this is therefore considered to be the subject that precedes the stative predicate.

A prominent idea to retain from the preceding argument is that subjects preceding the stative predicates do not denote the doer of the action. Instead they denote who/what the sentence is about.

As regurgitation, the subject of a sentence is who or what the sentence is all 
about.

\subsection{Classification of Subject}

One aspect worthy of note here is to borrow Sarah's (2015) words, "much like defining the subject is quite hard, the division of the term is also challenging". Theories behind the concept subject vary from language to language. Obviously, then, the categorization cannot be universal. Types of subject connected with English and Portuguese will hence be provided here, both languages being the ones under scrutiny.

In Svenonius' (2002: p. 3) classification of subjects, he distinguishes between the grammatical and logical subjects. These subjects are also referred to by the same author as formal and notional subjects, respectively. Indeed, Svenonius' division can be depicted by cleft sentences. An illustration includes:

(1) It was Carlos who got married.

In this sentence, for example, it is the formal subject while Carlos is considered to be the notional subject of this sentence. It therefore follows from sentence (1) that formal subjects fill the typical position of the subject in a sentence.

In addition to the above classification, Svenonius (2002: p. 5) mentions expletive subjects, which are, according to him, "identified by their lack of semantic content." He likewise adds that expletive subjects' resolutely grammatical nature "makes them an excellent probe into the boundary between syntax and semantics." It is unrealistic to end without mentioning that expletive subjects are also known as pleonastic, dummy and non-referential as they are discussed the section below.

It should be noted that in the literature on English subjects, non-referential subjects are of paramount importance. At this level, the question arises as to what non-referential subjects are. In the following sub-point, an answer is provided.

\subsection{Referential Versus Non-Referential Subject}

It is important to remind the readers of this paper that like many other languages, English allows dummy or non-referential subject. These subjects were tackled elsewhere in this same research. Here however, many details on them are included.

Svenonius (2002) reports expletive subject to be, either "extraposition it, weather it, and impersonal there". Elaborating on expletive subjects, Aarts (1997) calls them "an empty subject" for they have no meaning and divides them into the non-referential it and the existential there. As one may notice, Aarts uses nonreferential it to encapsulate Svenonius' both extraposition it and weather it. The non-referential it owes its name, Aarts (1997: p. 14) goes on to say "to the fact that it does not refer to anything in the sentence."

Celce-Murcia and Larsen-Freeman (1999) elaborated on non-referential subjects it and there arguing that the latter has "the same syntactic function as it 
does but which is used in different contexts". The former, in comparison, CelceMurcia and Larsen-Freeman go on to say "is extremely common in the modern English language and it can be used in four lexical contexts". These lexical contexts are time as in (2), distance as in (3), weather as in (4) and environment as in (5):

(2) It is half past six.

(3) It is about 45 kilometers from Cabinda to Cacongo.

(4) It is hot today.

(5) It is so dirty in this room.

The fact that the pronoun it is necessary in sentences (2) and (4) above can be compared to the example (6) and (7) below where it is shown that, in Portuguese, there is no need for the expletive pronoun it and the sentences are subjectless.

(6) São seis e trinta. $\longrightarrow{ }^{*}$ Are half past six.

(7) Está quente hoje. $\longrightarrow{ }^{\star}$ Is hot today.

It should also be said that Antonova-Ünlü (2015) quoting Murphy (1990) points out that, "non-referential it often appears in constructions with adjective + infinitive." Sentence (8) is an illustration:

(8) It is impossible to understand you!

The subject can also be expressed with the there which is called existential there since Aarts (1997: p. 10) says "it only defines the existence of something". In the sentence There was a man in the room, for example, "the existential there implies the existence of the man in the room", he argues.

If a conclusion be needed, the researcher will borrow Aarts' (1997: p. 10) words to conclude that expletive subjects or non-referential it and existential there are said to be meaningless "because all they seem to be doing in the sentences in which they occur is fill the subject slot."

\subsection{Subject-Verb Concord}

The subject in a sentence agrees with the verb in number and person, and can be substituted by a pronoun. Biber et al. (2013: p. 232) sustaining this view write:

the rule of subject-verb concord in English is that in finite clauses, the verb phrase in a clause agrees with the subject in terms of number (singular or plural) and person (first, second or third person).

It is Biber et al.'s (2013: p. 232) argument that for the verb be, the subject-verb concord is not only limited to the present tense. In the same way, they add that subject-verb concord is also limited to the present tense when it comes.

to the choice between the base form (e.g. walk) and the s-form (e.g. walks) of the finite verb. There is no subject-verb concord with modal auxiliaries, non-finite verbs, imperatives, or the subjunctive: these do not vary for number or person.

It should be mentioned that Biber et al. (2013: p. 232) note "the rules for sub- 
ject-verb concord are easy to identify but in practice not always easy to apply." They likewise add: "difficulties arise because 'singular' and 'plural' can be understood either in terms of form or in terms of meaning".

\subsection{The Null Subject}

As a reminder, there are languages which are referred to as null subject languages. These languages, Roberta (2014) points out "are those languages that can leave the subject of a sentence unexpressed." Kempchinsky (1984) takes a similar stance defining null subject languages. She says that null subject languages are "languages which allow subject position to be filled by a phonetically null element."

It is also important to note that null subject languages, also referred to as prodrop languages, have properties which distinguish them from non-null subject languages (see Kenstowicz, 1989; Jaeggli \& Safir, 1989; Rothman \& Iverson, 2007). These properties include Barbosa et al. (1995) report (a) having phonologically null subject pronouns (b) SV, VS order alternations (so-called "free subject inversion") and (c) lack of that-trace effects or that-trace violation: extraction is from post-verbal position. These properties are respectively shown in the sentence (9), (10) and (11), and (12):

(9) Fomos bons estudantes.

${ }^{*}$ Were good students.

(10) Chegaram os rapazes.

${ }^{\star}$ Arrived the boys.

(11) Viram os rapazes um gato preto. $\quad{ }^{\star}$ Saw the boys a black cat.

(12) Quem pensas que está fazendo tudo? ${ }^{\star}$ Who do you think that is doing everything?

The grammatical translations of the above Portuguese sentences into English should, however, be (9) We were good students. (10) The boys arrived. (11) The boys saw a black cat and (12) Who do you think is doing everything?

All in all, pro-drop or null subject languages are languages in which the subject can optionally be used and easily be understood from the context.

Unlike English and French, where the subject is obligatory, languages such as Portuguese, Italian, Spanish and many other languages are null subject languages. They are called pro-drop languages; the pro being written in small letters (governed by a verb with a full inflectional paradigm for subjects and objects) to distinguish it from PRO (big PRO) which is infinitival base subject. The case in the sentences John tried PRO to please Mary. and É possivel [pro sairem deste lugar].

\subsection{Inflection in Null Subject Languages}

Inflection is of paramount relevance in null subject languages. Aarts (2011: p. 20) observes that inflection:

...is a notion which is concerned with the alternative forms, called inflectional forms that lexemes can take, as determined by the syntactic environ- 
ment they occur in. Inflection is a morpho-syntactic notion, which means that it is a phenomenon that is relevant both to syntax and morphology. Inflections are typically realized by different suffixes.

It should be noted that in null subject languages, the subject may be conveyed by the inflection of the verb. Portuguese, for example, is sufficiently rich in this. In Portuguese, subjects are omitted when the verb provides enough morphological information about it, e.g. inflection signalling person and number agreement. The verb "cantar" (to sing) as used in the example (13) will be used henceforth to clarify the researcher's view. (14) Cant-o (I sing) is the first person. Other persons include:

$\begin{array}{lll}\text { cant-as } & \text { you (sg.) sing } & 2^{\text {nd }} \text { person singular } \\ \text { cant-a } & \text { he/she sings } & 3^{\text {rd }} \text { person singular } \\ \text { cant-amos } & \text { we sing } & 1^{\text {st }} \text { person plural } \\ \text { cant-ais } & \text { you (pl.) sing } & 2^{\text {nd }} \text { person plural } \\ \text { cant-am } & \text { they sing } & 3^{\text {rd }} \text { person plural }\end{array}$

The afore-mentioned example illustrates that the ending of the verb varies widely in all six persons. It is impossible to denote the perplexity because the different inflectional affixes of the verb immediately identify the subject. Therefore, in Portuguese, it is optional to use the subject because of the identification.

English, on the other hand, does not permit thematic null subjects, it does allow the referential and non-referential (it and the existential there) subjects to remain in sentence. Therefore, the English verbs cannot define the missing subject pronoun.

An important idea to retain from this discussion is that, null subject languages need to have a rich inflection. In other terms, inflection is of great importance to null subject languages, mainly verb inflection since it is the key feature in the identification of the non-phonological subjects. The researcher reminds the readers in assuming that null subject sentence formulation occurs if the unexpressed subject is considered to be personal pronoun.

\section{Method}

It is important, then, to remind the readers of this paper that the aim behind this investigation is to see the influence of Portuguese syntax on the learning of English, mainly the influence of Portuguese phonological null subjects on the pupils' formulation of English sentences. For this purpose, a test was designed and administered to pupils.

\subsection{The Sample}

It should be noted that the sample of this research is composed of 30 subjects. These subjects were selected at random from IMEC, a school located at Cabassango, in Cabinda. The sample consisted of fifteen $11^{\text {th }}$-graders of "Class B7" and fifteen $11^{\text {th }}$-graders of "Class B8". 
Their age ranged from 16 to 22 years and the sample included 26 male respondents and 4 female respondents.

\subsection{Methodology}

For the purpose of this study, both qualitative and quantitative methods were adopted. The qualitative method will help describe the learners' errors. The quantitative analysis, on the other hand, will use statistical computations and tests in order to verify the validity or invalidity of the research hypotheses. The statistical tests used in this research are the $\mathrm{t}$-test and the matched $\mathrm{t}$-test.

\subsection{The Instrument}

The term instrument is used here to refer to the test which the researcher designed in order to collect data from his examinees. In fact, the researcher designed a test which consisted of two parts: the first part is an elicitation of the subjects' biographical information; the second consists of a translation task.

The test as a whole contained 10 sentences related to the research problem and hypotheses. Pupils had to translate these 10 sentences written in Portuguese into English. The test's total score was 10. That is, each sentence was scored 1. To put it clearly, the subjects who correctly translate the 10 sentences will get 10 .

\subsection{The Test Administration}

The researcher administrated a pilot study before the final administration of the test. The pilot study helped in discovering the weaknesses of the test and by the same token to correct it.

The final administration of the test took place on May 14, 2021 under the researcher's supervision. To avoid disparity in the results, both groups were assigned the same test.

\subsection{The Test Correction}

The purpose of the investigation was to verify whether Portuguese syntax, especially the null Portuguese subject had an influence on the $11^{\text {th }}$-graders' formulation of the English sentences. Thus, in the test correction, the researcher only looked at the subject presence or absence regardless of the formulation of the sentence.

Portuguese sentences translated into English are listed below:
1) Sou bom aluno.
2) É o meu primo.
3) Comeram carne.
4) Choveu muito ontem.
5) Sim, é.
6) Entregou-me o dinheiro.
7) Caiu à lama.
8) Parece que chegou ontem. 
9) Soube que passaste a prova.

10) Seria bom para ti.

The researcher corrected the test himself and to avoid subjectivity, he took care of using a reference sheet on which all the expected answers were written. A detail worthy reminding here is that the score per individual item was 1 . For each right translation, the researcher scored 1 and for each wrong translation he scored zero.

\subsection{Data Presentation}

This subpoint focuses on how he collected, organized and presented the research data. After the researcher had corrected the test, he presented the data in tabular forms. Tables 1-3 are therefore presented hereafter. The tables include 4 columns: the sentence number in the test, the expected answers, the number of subjects' wrong and right translations.

\subsection{Data Analysis}

It follows from the subjects' performance tables presented in the Section 2.6 of this research that the subjects made more wrong translation than the right counterparts.

\subsection{Linguistic Analysis}

It is important that the data collected through the test be subjected to a linguistic analysis so that the subjects' language is described with regards to its morphological, syntactical, and semantic structures.

The results obtained show that only 42 out of 300 expected translations, that is, $14 \%$ of sentences were translated correctly into English. The remaining $86 \%$ of translations were wrong, that is, they lacked the subject. These observations

Table 1. $11^{\text {th }}$-graders of class B7's performance in the translation of the portuguese sentences containing null subjects.

\begin{tabular}{clcc}
\hline Sentence & \multicolumn{1}{c}{ Targeted answers } & $\begin{array}{c}\text { Right } \\
\text { translations }\end{array}$ & $\begin{array}{c}\text { Wrong } \\
\text { translations }\end{array}$ \\
\hline 1 & I am a good pupil & 7 & $\mathbf{8}$ \\
2 & It/he is my cousin. & 3 & 12 \\
3 & They ate meat. & 1 & 14 \\
4 & It rained a lot yesterday & 1 & 14 \\
5 & Yes, it is. & 0 & 15 \\
6 & He/she gave me the money. & 1 & 14 \\
7 & He/she fell in the mud. & 1 & 14 \\
8 & It seems he/she has already arrived. & 1 & 14 \\
9 & I knew that (you) passed the exam. Congratulations! & 1 & 14 \\
10 & It will be good for you. & 1 & 14
\end{tabular}


Table 2. $11^{\text {th }}$-graders of class B8's performance in the translation of the portuguese sentences containing null subjects.

\begin{tabular}{clcc}
\hline Sentence & \multicolumn{1}{c}{ Targeted answers } & $\begin{array}{c}\text { Right } \\
\text { translations }\end{array}$ & $\begin{array}{c}\text { Wrong } \\
\text { translations }\end{array}$ \\
\cline { 2 - 4 } 1 & I am a good pupil & 7 & 8 \\
2 & It/he is my cousin. & 2 & 13 \\
3 & They ate meat. & 6 & 9 \\
4 & It rained a lot yesterday & 1 & 14 \\
5 & Yes, it is. & 1 & 14 \\
6 & He/she gave me the money. & 2 & 13 \\
7 & He/she fell in the puddle. & 3 & 14 \\
8 & It seems he/she has already arrived & 1 & 12 \\
9 & I knew that (you) passed the exam. Congratulations! & 1 & 14 \\
10 & It will be good for you. & & 14 \\
\hline
\end{tabular}

Table 3. Overall performance of $11^{\text {th }}$-graders of B7 and B8 in the translation of the portuguese sentences containing null subjects.

\begin{tabular}{clcc}
\hline Sentence & \multicolumn{1}{c}{ Targeted answers } & $\begin{array}{c}\text { Right } \\
\text { translations }\end{array}$ & $\begin{array}{c}\text { Wrong } \\
\text { translations }\end{array}$ \\
\cline { 2 - 4 } 1 & I am a good pupil & 14 & 16 \\
2 & It/he is my cousin. & 5 & 25 \\
3 & They ate meat. & 7 & 23 \\
4 & It rained a lot yesterday & 2 & 28 \\
5 & Yes, it is. & 1 & 29 \\
6 & He/she gave me the money. & 3 & 27 \\
7 & He/she fell in the mud. & 2 & 28 \\
8 & It seems that he/she came yesterday. & 4 & 26 \\
9 & I knew that (you) passed the exam. Congratulations! & 2 & 28 \\
10 & It will be good for you. & 2 & 28 \\
\hline
\end{tabular}

imply that the pupils dropped the English subject due to the influence of Portuguese. In fact, the linguistic analysis carried out in this research reports ten subjects production of such English sentences as (a)* am good student, (b) *Is my cousin, (c)* ate meat, (d) *rained a lot yesterday, (e) *yes, is, (f) *handed me the money, (g) *Fell into the mud, (h) *seem that arrived yesterday, (i) *Knew that passed the exam, $(j) *$ Would be good for you.

It is to be said here that although a stint in reading the data presented in the tables and linguistic analysis undertaken by the researcher are a proof that $11^{\text {th }}$ graders experience problems in the formulation of the English sentences due to the influence of their L1, mention should be made, however, that these observation are not enough to draw reliable conclusions. Statistical tests are yet to be done in order to validate or invalidate the research hypotheses. 


\subsection{Statistical Analysis}

It sets out to analyze the pupils' data on the basis of statistical tests. One important thing to note is that the researcher used statistical tests to supplement the linguistic analysis. These tests helped the researcher to validate or invalidate the two hypotheses of the current research. It should be noted that the first hypothesis was examined with the matched t-test. The last hypothesis, on the other hand, was examined using the $t$-test.

\subsection{Results Interpretation}

The researcher reminds his readers that the research hypotheses were tested at $5 \%$ level of significance.

Hypothesis 1: If there is L1 possibility of null subject transfer in the formulation of English sentences, then $11^{\text {th }}$-graders will often drop the English subject.

Considering this first hypothesis stated above, at the $5 \%$ level of significance, the $\mathrm{t}$-read in the table is 2.04, and the $\mathrm{tc}_{1}$ (matched $\mathrm{t}$-calculated) is 1 . One sees clearly that the calculated value is lower than the $t$-read, that is, $1<2.04$; the matched t-test result is $\mathrm{t}=1, d f 29, p<0.000$. This implies that the first hypothesis is validated. Clearly, the influence of Portuguese is significant. This hypothesis was tested out using the matched $t$-test which compares the means of one group in two different items.

It is known that in Angola, Portuguese has a certain ascendancy over English in that it is by far the most used language at school and outside the school. English is used but not in the same way as Portuguese. Thus, pupils transfer the Portuguese realities into English forgetting that what works in Portuguese may not work in English: the subject use being a perfect case.

Hypothesis 2: It is expected that $11^{\text {th }}$-graders of "Class B8" outperform those of "Class B7" as far as the English subject is concerned.

From Table 2, the researcher calculated the t-test to confirm or reject the second hypothesis. The final result obtained here was $t_{c}=0.47, \mathrm{df}=29, p<0.5$. At $5 \%$ level of significance the $\mathrm{t}$-read is 2.04 . One realizes that the $\mathrm{t}$-calculated is inferior to the $\mathrm{t}$-read, that is, $0.47<2.04$ and in the testing criteria, the second hypothesis is validated. This result implies that $11^{\text {th }}$-graders of "Class B8" exhibited a slightly higher score than those of "Class B7" regarding the use of the English subject. More precisely, the $11^{\text {th }}$-graders of "Class B7" encountered more difficulties regarding the use of the English subject than those of "Class B8". Note should be made, however that this difference between the two groups is only due to chance for both classes are taught by the same teacher.

\subsection{Findings}

The various statistical processes used in this chapter helped the researcher to support or reject the hypotheses in the theoretical arguments of the research. It should be reminded that the final results arrived at supported the two hypothes- 
es formulated in this research. In this respect, the key findings of a research include the validation hypotheses

\subsection{The Source of Errors}

This subpoint concentrates on the sources of errors in the learners' interlanguage. Two sources of errors have been identified by the researcher. These sources include, on the one hand, the learners' insufficient grammatical competence and the paucity of their exposure to the target language. On the other hand, language transfer prompts the learners to produce so many ungrammatical English sentences.

\subsection{Language Transfer}

As stated in Webster's Third New World International Dictionary (1986) transfer is "the carry-over or generalization of learned responses from one type of situation to another." In language transfer, Terence Odlin (1989: p. 27) points out a working definition for transfer as "the influence resulting from similarities and differences between the target language and any other language that has been previously (and perhaps imperfectly) acquired." In the line of ideas, he adds that:

the influence arises from a learner's conscious or unconscious judgment that something in the native language (most typically) and something in the target language are similar, if not the same.

It was observed in this research that the participants carried over the Portuguese influence to English. One example of this observation is the frequent omission of the English subject. Such omission is not typical of English, where the subject is obligatory. This state of affairs prompted the pupils to produce such sentences as:

1) *am good student instead of I am a good student.

2) * is my cousin instead of $\mathrm{He}$ is my cousin.

3) *ate meat instead of They ate meat.

4) *rained a lot yesterday instead of It rained a lot yesterday.

5) $*$ Yes, is instead of Yes, it is.

6) *handed me the money instead of $\mathrm{He} /$ She handed me the money.

7) * fell into the mud instead of $\mathrm{He} / \mathrm{She}$ fell in the mud.

8) * seems that arrived yesterday instead of It seems he/she has already arrived.

9) *knew that passed the exam. Congratulations! instead of I knew that (you) passed the exam. Congratulations!

10) *would be good for you instead of It would be good for you.

\subsection{Inadequate Exposure to the Target Language}

Many linguists are convinced that language is learnt through use and practice. In this respect, pupils need to be provided with more opportunities to use and prac- 
tice the language in meaningful context. Krashen (1982) points out that "living in a country where the language is spoken can result in an all-day second language lesson!" In fact, exposure is crucial in enhancing competence in the target language. Krashen (1982) goes on to say that learners "need to know enough of the second language so they can understand significant portions of non-classroom language". In this line of ideas, Wilkins (1972) quoted by Jamali (1991) argues, "in the natural L2 learning situation, the pressure to acquire the target language in order to control the environment is indeed tremendous."

Unfortunately, in such country as Angola, Portuguese is both the learners' L1 and the language of instruction, English is learned as a foreign language, only as a school subject. The preceding view is in line with Haja Mohideen's (1996) argument, which runs as follows:

Learners who live in a country where English is taught as a foreign language obviously do not have adequate exposure to the target language. Opportunities to use English in both the productive and receptive areas of the language are limited.

Hence, in the context of Angola which is a highly Portuguese dominated landscape, the majority of learners are not normally exposed to English.

\section{Recommendations}

Given the problem this paper states, the researcher provides some recommendations with a view to improving learners' overall performance in English. These recommendations concern the main influences involved the teaching/learning process.

\subsection{The EFL Teachers' Role}

In the teaching of the English subject, the teacher is advised to draw learner' attention to this difference. He must tell his learners that unlike the Portuguese subject, the English subject cannot be dropped. Doing so will generate ungrammatical English sentences.

\subsection{For the Amount of Exposure}

The empirical research reported inadequate exposure to the target language as one of learners' source of errors. To increase the learners' amount of exposure to the target language, the researcher suggests the creation of a school English club. This club will provide learners opportunities to practice the target language.

\subsection{The Learners' Role}

The learner is viewed at the centre of the teaching/learning process. He is a collaborator and a group member. He should be efficient participant and practice the real-world English for a purpose that is interesting to him. To put it differently, the learner needs to be engaged in the learning process. 


\section{Conclusion}

The present paper has dealt with the influence of Portuguese syntax on the learning of English: the case of null subject. Indeed, it appeared difficult to guess the content of this work from its title. Now that the work has come to a finish, the researcher is convinced that the topic of this research summarizes the content of the whole paper. It indicated that Portuguese-speaking learners of English were keen on dropping the subject in their construction of English sentences. Portuguese is, as has been argued elsewhere in this same paper, a null subject language. In a Portuguese sentence, the subject can be dropped and the person and the number are carried by the verb. This is not the case with English, which compulsorily needs an overt subject to appear in the sentence.

\section{Conflicts of Interest}

The author declares no conflicts of interest regarding the publication of this paper.

\section{References}

(1986). Webster's Third New World International Dictionary.

Aarts, B. (1997). English Syntax and Argumentation. Macmillan Press Ltd. https://doi.org/10.1007/978-1-349-25589-4

Aarts, B. (2011). Oxford Modern English Grammar. Oxford University Press.

Antonova-Ünlü, E. (2015). Can the Pro-Drop Parameter Account for All the Errors in the Acquisition of Non-Referential It in L2 English? Revue Canadienne de Linguistique Appliquée, 18, 21-41.

Barbosa, P., Maria, E. L. D., \& Mary, A. K. (1995). Null Subjects in European and Brazilian Portuguese. Journal of Portuguese Linguistics, 4, 11-52.

Biber, D., Conrad, S., \& Leech, G. (2013). Longman Student Grammar of Spoken and Written English. Longman.

Carter, R., \& McCarthy, M. (2012). Cambridge Grammar of English: A Comprehensive guide Spoken and Written English Grammar and Usage. Cambridge University Press.

Celce-Murcia, M., \& Larsen-Freeman, D. (1999). The Grammar Book: An ESL/EFL Teacher's Course. Heinle and Heinle Thomson Publishing.

Cunha, C., \& Cintra, L. F. (2001). Nova Gramática do Português Contemporâneo. Editora Nova Fronteira.

Haja, M. (1996). Error Analysis: Contributory Factors to Students' Errors with Special Reference to Errors in Written English. The English Teacher, 25, 46-49.

Hyams, N. (1989). The Null Subject Parameter in Language Acquisition. In O. Jaeggli, \& J. K. Safir (Eds.), The Null Subject Parameter (pp. 215-238). Kluwer.

Jaeggli, O., \& Safir, J. K. (1989). The Null Subject Parameter. Kluwer. https://doi.org/10.1007/978-94-009-2540-3

Jamali, L. (1991). Language Exposure and Second Language Learning. The English Teacher, 20, 236-263.

Kempchinsky, P. (1984). Brazilian Portuguese and the Null Subject Parameter. University of California. 
Kenstowicz, M. (1989). The Null Subject Parameter in Modern Arabic Dialects. In O. Jaeggli, \& J. K. Safir (Eds.), The Null Subject Parameter (pp. 263-275). Kluwer.

Krashen, S. D. (1982). Principles and Practices of Second Language Acquisition. Pergamon Press.

Liceras, M. J., \& Díaz, L. (1999). Topic-Drop versus Pro-Drop: Null Subjects and Pronominal Subjects in the Spanish L2 of Chinese, English, French, German and Japanese Speakers. Second Language Research, 15, 1-40. https://doi.org/10.1191/026765899678128123

Odlin, T. (1989). Language Transfer. Cambridge University Press. https://doi.org/10.1017/CBO9781139524537

Prentza, A. (2014). Can Greek Learners Acquire the Overt Subject Property of English? A Pilot Study. Theory and Practice in Language Studies, 4, 1770-1777. https://doi.org/10.4304/tpls.4.9.1770-1777

Roberta, D. A. (2014). The Null Subject Parameter. Where Are We and Where Are We Headed? Leiden University Centre for Linguistics.

Rothman, J., \& Iverson, M. (2007). The Syntax of Null Subjects in L2 Spanish: Comparing Two L2 Populations under Different Exposure. RESLA, 20, 185-214.

Sarah, M. (2015). Subject Position in English, Portuguese and Croatian.

Svenonius, P. (2002). Subjects, Expletives and the EPP. Oxford University Press.

Valian, V. (1990). Null Subjects: A Problem for Parameter-Setting Models of Language Acquisition. Cognition, 35, 105-122.

White, L. (1985). The Pro-Drop Parameter in Adult Second Language Acquisition. Language Learning, 35, 47-62.

White, L. (1993). Universal Grammar: It Is Just New Name for Old Problems? In S. Gass, \& L. Selinker (Eds.), Language Transfer in Language Learning (pp. 217-232). Newbury House.

Wilkins, D. A. (1972). Linguistics in Language Teaching. 